\title{
Translation difficulties in the Romanian version of Arthur Schopenhauer's Aphorisms. A contrastive and diachronic analysis (II)
}

\author{
Cecilia-Iuliana Vârlan* \\ Faculty of Letters, “Ovidius” University, Aleea Universității 1, 900472 Constanța, Romania
}

\section{Article info}

History:

Received April 21, 2016

Accepted May 27, 2016

Published August 1, 2016

Key words:

translation

diachrony

comparative analysis

\begin{abstract}
This paper continues the linguistic analysis on various editions of the Romanian version of Arthur Schopenhauer's late philosophical work Aphorisms on the Wisdom of Life, an analysis which was conducted along two research directions that have been here preserved: the contrastive one (a direct comparison between source-text and target-text) and the diachronic one (considering the translator's interventions on his own text at different points in time). The results of this analysis shall be presented here along the conclusions of the linguistic approach performed in order to objectively observe the way the translator, Titu Maiores$\mathrm{cu}$, solved the difficulties of translating a German philosophical text into Romanian, by recording both his achievements and his imperfections.

The linguistic approach of our analysis is useful not only to our discussion on philosophic translation, but also to possible forthcoming translators of the Aphorisms, whose intention might be that of adapting the discourse of the existent Romanian version written by Titu Maiorescu to the possibilities of Romanian contemporary language, considering its considerable evolution, especially as far as philosophical terminology is concerned.
\end{abstract}

\section{Introduction}

This paper resumes the detailed analysis of the Romanian version of the chapter called "Introduction" (Einleitung) of Arthur Schopenhauer's Aphorisms on the Wisdom of Life (Aphorismen zurLebensweisheit) ${ }^{1}$. The analysis has been started in a previously published article, in which all details regarding working method and material have been given, cf. Vârlan (2016).

At the end of the analysis, results and conclusion shall be presented with the aim of revealing both the way the author of the Aphorisms organised his discourse-considering the lexis, the semantics and the stylistics involved in structuring his text in order to obtain certain cognitive and aesthetic effects-and the extend to which his text has been pragmatically understood by the translator and correctly rendered into Romanian.

\section{A contrastive-diachronic analysis of the Romanian version of Aphorisms (cont'd)}

The contrastive-diachronic analysis conducted on the text discussed here is, in fact, a pragmalinguistic analysis and it involved the examination of similarities and differences between various translating options the translator adopted in various moments over a certain period of time. Thus, the interventions the author made in his own text in various moments of over the period of time he made his Romanian version of a German philosophical text have been both contrastively and diachronically analysed.

\footnotetext{
*Email address: varlan_c@yahoo.com.

${ }^{1}$ Hereinafter referred to as Aphorisms.
} 
The working method that was used for the first part of our analysis has also been here preserved, i.e. the text was divided into sentences numbered from (1) to (14), while the corresponding Romanian editions of translation, $A_{72 / 76}, A_{90}$, and $A_{12}$, have been successively positioned under each of them.

The first part of our analysis examined the first five sentences of the text we discuss here. In the next sentence, (6), Arthur Schopenhauer continued his critical perspective on eudemonology by comparing it to his own philosophical system. His critical point of view took the form of justifying his working method as it was required by the inherent limitations of the theory he was working with.

(6) Um eine solche dennoch ausarbeiten zu können, habe ich daber gänzlich abgehn müssen von dem höheren, metaphyf[s]isch-ethischen Standpunkte, zu welchem meine eigentliche Philosophie hinleitet.

$\mathrm{A}_{72 / 76}$ Pentru a prelucra dar totuşi o asemenea invěțătură, am trebuit să mě depărtez de la punctul de vedere mai inalt, spre care conduce filosofia mea in propriul ințeles al metafisicei ei etice.

$\mathrm{A}_{90} \quad$ Pentru a scrie dar o asemenea călăuză, am trebuit să mě depărtez de la punctul de vedere mai inalt, spre care conduce filosofia mea in adevěratul ințeles al moralei ei metafisice.

$\mathrm{A}_{12} \quad$ Pentru a scrie dar o asemenea călăuză, a trebuit să mă depărtez de la punctul de vedere mai inalt, spre care conduce filozofia mea în adevăratul înțeles al moralei ei metafizice.

The sentence (6) in the source-text began with an infinitive phrase introducing a final clause: $u m$... zu .... The Romanian translator used the same type of construction, 'pentru + infinitive', with a slight position change of its elements in order to comply with the Romanian language word order.

Immediately after the preposition $u m$, the reader of the original text has to find the meaning of the anaphoric demonstrative pronoun eine solche, whose referent may be easily found in the noun Eudämonologie. In order to facilitate the logical understanding of the translated text, Titu Maiorescu partially dismissed the anaphor by specifying the referent, using - thus-a synonym for the referent in the original text. Nevertheless, the anaphoric intention of the original author was preserved by the adjective asemenea. Thus, eine solche became o asemenea invěțătură in $\mathrm{A}_{72 / 76}$, and $o$ asemenea călăuză in $\mathrm{A}_{90}$ and in $\mathrm{A}_{12}$. We have noticed that T. Maiorescu has initially chosen for the noun eudemonologie a synonym of Latin origin, invéțătură, but after the revision of his translation, he decided to use another noun, călăuzăa of Turkish origin. This choice of words was probably made with the intention of limiting the semantic range of invêțătură, which beside 'sfat, povațằ can more generally mean 'instruire, 'instrucțiune', 'știință de carte, erudițiune' (Șăineanu, 1908, p. 339) ${ }^{2}$.

The German infinitive phrase um ... zu... is built with a modal verb: ausarbeiten zu können. T. Maiorescu chose to under-translate the phrase, by eliminating the modal from the Romanian version. The infinitive of the notional verb was nevertheless preserved as such, in accordance with the norms of the standard Romanian language. The infinitive was initially transposed as a prelucra, while a scrie occurred in the subsequent editions of translation. Again, the translator's intention was to facilitate his readers the understanding of the text by limiting the meaning of the German verb ausarbeiten to only one practical example from the list of actions implied by its semantics, which in this case was the action of writing.

Translation difficulties deriving from the insufficient development of Romanian philosophical language are especially obvious when considering Romanian equivalents of the following German noun phrase (in the present article, 'noun phrase' is used as a synonym for 'nominal group'):

... [von dem] höheren, metaphysisch-ethischen Standpunkte, zu welchem meine eigentliche Philosophie hinleitet.

\footnotetext{
${ }^{2}$ An additional meaning for the noun călăuz (călăuză) is also indicated by Lazăr Șăineanu in the sense of leading someone along a specific road, by giving indications and advice; thus, both literal and figurative meanings are here implied.
} 
The initial Romanian translation was:

[de la] punctul de vedere mai inalt, spre care conduce filosofia mea in propriul inteles al metafizicei ei etice.

The nominal group in the source-text includes a centre (the compound noun Standpunkte), two adjectives, which were positioned before the compound noun, in accordance with the syntax of German language (höheren and metaphysisch-ethischen), and an attributive relative clause positioned right after the centre (zu welchem meine eigentliche Philosophie hinleitet).

As a Romanian equivalent for the noun Standpunkte, the Romanian translator used a noun phrase that includes a noun (punctul) and a prepositional phrase (de vedere); this translation strategy is actually the norm by translating German compounds into Romanian. Although the noun Standpunkte may seem as being marked for plural, both its definite article in dative dem and the relative pronoun welchem in the subordinated clause that follows it clearly indicates that the respective noun is a singular. In this case, the ending vowel e is not a mark for plural, but an additional vowel that used to be employed as a specific ending for masculine or neuter nouns in dative. This phenomenon has been regarded as a rule for the written German language until approximately the half of the $20^{\text {th }}$ century, when it began to disappear (cf. Rieger, 2006/2007,p. 1). Considering his educational background, Titu Maiorescu was certainly familiar with the norm of the German language of the times when the source-text had been written, so that he had not been tricked by the form of the noun, as it may happen today to any inexperienced translator.

Different translating strategies have been used for transposing the two adjectives preceding the centre of the nominal group. The first one, höheren, was literally translated as mai inalt, though, in our opinion, considering the fact that it describes an abstract noun, a contextual transposition would have been more appropriate, for example superior, elevat, even rafinat.

In his effort of finding an equivalent for the second adjective, the compound metaphysisch-ethisch(en), T. Maiorescu employed modalisation as a translating strategy by changing the compound word into a nominal group. In the $\mathrm{A}_{72 / 76}$ edition, the first adjective of the compound was translated as a noun that became the centre of the nominal group, metafizic $\breve{a}$, while the second adjective became an attribute for this noun, etică. The subsequent editions of translation, which are identical with one another except for minor orthographical changes, displayed a reversed attribution of morphological values, whereas instead of using etică as a noun, the translator decided to use the synonym morala. Thus, metafizica etică from the first edition becomes now morala metafizică.

The attributive relative clause which was positioned after the centre Standpunkte was translated by T. Maiorescu literally, all with the exception of the adverb eigentlich. He decided to extract it from the relative clause and attach it to the noun phrase resulted from the translation of the compound adjective metaphysisch-ethisch(en). In doing this, the translator had to build an additional phrase functioning as an adverb: in propriul inteles al metafizicei ei etice (in $\mathrm{A}_{72 / 76}$ ) or in adevăratul ințeles al moralei ei metafizice (in $\mathrm{A}_{90}$ and $\mathrm{A}_{12}$ ). When comparing these two options of translation, one could notice that beside the morphological changes we discussed above, the translator also introduced an additional noun (inţeles) into this phrase. The adverb eigentilich became an adjective for it, initially as propriul, and, in subsequent editions, as adevăratul. So, in this case, the translator decided for both modalizing the source-text and over-translating it, by adding new message to the original one.

It is extremely obvious that finding an appropriate Romanian equivalent for this sentence implied great difficulties which the translator tried to overcome by adopting various strategies. T. Maiorescu's hesitations and revisions of his text, especially as far as this sentence is concerned, prove the effort and tenacity of a translator trying to solve the linguistic problems deriving from a certain incapacity of Romanian language of the time the translation was written to cover complex semantic areas of German lexemes, especially of those belonging to the specialized language of philosophy.

Today, over one century after the time Titu Maiorescu wrote his translation from Arthur Schopenhauer's Aphorisms, when more linguistic resources are at hand as far as contemporary Romanian language 
is concerned, we dare to advance another solution for translating this sentence, as follows:

De aceea, pentru a putea construi, totuşi, o astfel de teorie, a trebuit să renunț în totalitate la viziunea elevată, metafizică și etică, la care se referă, de fapt, filosofia mea.

The version we advanced here assumed a series of translating strategies used by Titu Maiorescu and attempted, at the same time, at both covering for some deficiencies of the original translation and at simplifying the text meaning for Romanian readers. For instance, the causal adverb daher had no equivalent in Titu Maiorescu's verstions of translation, while in our version it appears as de aceea. Its occurrence at the beginning of the translated sentence was determined by the pragmatic intent of the original writer, which is that of justifying his scientific approach and which we also wished to emphasize. Also, the modal verb has been preserved in the equivalent of the infinitive phrase um .... ausarbeiten zu können, whereas for ausarbeiten the equivalent a construi (Eng. to build) was chosen. T. Maiorescu used a prelucra (Eng.: to elaborate) in $\mathrm{A}_{72 / 76}$ and a scrie (Eng.: to write) in later editions. On one hand, the verb a prelucra is a literal translation of ausarbeiten, whose meaning implies that there already existed a concept, which the actant wanted to develop or to elaborate. This may seem in accordance with the real fact that the concept of eudemonology had not been coined by the writer of the original text. Moreover, Arthur Schopenhauer himself listed a number of foregoers who had already made use of the concept in their writings. On the other hand, the verb a scrie does not seem to cover the meaning of conceiving a theory, but only that of writing it down. Those were the reasons that led us to finding another equivalent for the German verb. There are a lot of synonyms for ausarbeiten in contemporary German language and from this list of synonyms we decided for the Romanian equivalent a construi because we considered a theory-especially a philosophical one-as being built, metaphorically speaking, starting from specific hypotheses as basis for building a rational thought and, then, for establishing certain conclusions.

The adverb gänzlich is another lexeme whose equivalent is not to be found in any of Titu Maiorescu's versions of translation and which we included in our version as in totalitate, because we considered its presence in the Romanian text as extremely necessary since it gives the measure of the difference between the concepts he used in the work we are reading and the ones he operated with in his philosophical system, mentioned by A. Schopenhauer himself as being his main work. In the same regard, we decided for viziunea as a Romanian equivalent for Standpunkte, since it is an abstract noun and more appropriate to describe a complex philosophical approach. Adopting the same logic, we chose the adjective elevată as its attribute, in order to both emphasize the difference mentioned above and partially preserve a fraction of the author's attitude, depreciative as it was, towards the work we are just reading compared to his previous philosophical works.

Returning to the source-text, one can notice that the next sentence (7) brings further in the most mathematical way the reasoning the author started in the previous sentence (6), by showing the consequences his present approach might have, an approach that include a certain alienation from the philosophical concepts elaborated in his previous works.

(7) Folglich beruht die ganze hier zu gebende Auseinandersetzung gewissermaßen auf einer Ackommodation, sofern sie nämlich auf dem gewöhnlichen, empirischen Standpunkte bleibt und dessen Irrthum festhält.

A $72 / 76$ Prin urmare toată expunerea făcută in scrierea de faţă provine oarecum dintr'o acomodare, intru căt remăne in marginile ințelegerii empirice obicinuite și-i continuă rátăcirea.

A 90 Prin urmare toate explicările cuprinse in scrierea de faţă provin oare-cum dintr'o acomodare, intru cât pornesc din punctul de vedere al experienței obicinuite și urmează drumul ei cel rătăcit.

$\mathrm{A}_{12}$ Prin urmare, toate explicările cuprinse in scrierea de față provin oarecum dintr-o acomodare, întrucît pornesc din punctul de vedere al experienței obişnuite și urmează drumul ei cel rătăcit. 
Comparing the $A_{72 / 76}$ and $A_{90}$ editions ( $A_{12}$ is relatively identical with $A_{90}$, except for some minor orthographic changes), the existence of further translating difficulties is being noticed again, at the level of both syntax and morphology.

The sentence started with the adverb folglich, for which T. Maiorescu easily found an adverbial phrase in Romanian language, prin urmare. Both the adverb and the adverbial phrase signal the introducing of a consequence or an outcome in the respective text.

The first nominal group in the source-text preserved its morphological value in the target-text, though different translating options are adopted in the two editions we discuss here. So, in $\mathrm{A}_{72 / 76}$, the Romanian equivalent of Auseinandersetzung, the centre of the nominal group, is expunerea, while in $A_{90}$ is a noun in plural, explicările. Thus, when revising his translation for its publication in 1890, T. Maiorescu decided not only to change the noun, but also its grammatical category of number. The translator probably regarded the plural as more appropriate to covering the semantics of the German noun, which implies a profound and especially complex preoccupation for a certain subject or topic.

This first nominal group includes also a synthetic grammatical form of the type $z u+$ Partizip I (also called Gerundive), which is used as an attribute and acts as an adjective, bearing all markings deriving from the agreement with the modified noun. This type of grammatical form is characteristic to German language and its meaning is determined by the verb it was derived from, here the German verb geben. Semantically speaking, the actual state of facts suggested by this grammatical form indicates a realistic and attainable goal in the future. Moreover, the passivisation of the verb action is here detectable by means of replacing the respective phrase with a relative, as in the examples below (Engel et al., 1993, p. 356-357):

Germ. die zu liefernde Ware (die Ware, die geliefert werden muß/soll) - Rom. „marfa de livrat (marfa care trebuie livrată / urmează să fie livrată)" [the goods to be delivered]

or

Germ. eine kaum zu verstehende Situation (eine Situation, die kaum verstanden werden kann) - Rom. „o situație greu de înțeles (o situație care poate fi greu înțeleasă)” [a situation hard to understand].

In Romanian, the equivalent of an attributive Gerundiv is built with the verb it was derived from, in the supine case, as seen above (de livrat, or de ințeles).

Titu Maiorescu neglected this translating rule and used directly a participle as a modifier: făcută in $\mathrm{A}_{72 / 76}$, and cuprinse in $\mathrm{A}_{90}$ and later editions. Here, the translator's hesitations are only apparent, since the modifying participle was chosen in direct accordance with the modified noun. In addition, Romanian

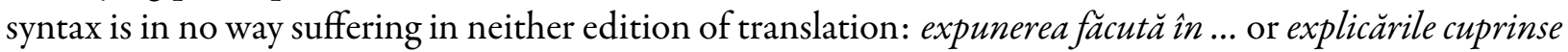
in ..., respectively. Nevertheless, it is true that by using the Gerundive form of the verb geben as an adjunct for the noun Auseinandersetzung the author set a semantic ambiguity in the text, in the sense that the actant of the verb action remained grammatically unnamed, so that the passive meaning was unavoidable. Therefore, a quasi-literal translation for the Gerundive discussed here would involve a relative clause (ce urmează a fi dată/date aici), but this translating strategy would also be responsible for a poor style, if not even deficient. We regard both versions as instances of Titu Maiorescu's creativity in finding the most appropriate equivalent of the verb geben by using what a theoretician of translation studies called "the compensatory virtues of Romanian language" (Kohn, 1983).

Our contrastive analysis found another point of interest in the translation of the German noun Ackommodation, which is a neologism originating in the Latin word accommodation. The word is used today (orthographically slightly modified: Akkommodation) in the field of physiology-where it refers to the ability of the human eye to see clearly in various distances; its Romanian equivalent acomodație belongs to the specialized language - and in the field of theology_here it refers to an adaptation / aligning / harmonizing of a religion to or with another religion's values and ideas. Titu Maiorescu chose to translate the word literally as acomodare, though the meaning of this Romanian equivalent did not correspond with 
the semantic range of the discussed neologism in the source-language. (cf. Şăineanu, 1908, p. 5). It is a known fact that Arthur Schopenhauer made use of German language vocabulary in a very personal way and he even invented new words by means of (unexpected) juxtaposition, listed by no dictionaries (cf. Hochfeld, 1912, p. 103-104). Here, he borrowed a word belonging to a specialized language other than the philosophical one. By doing that, he opened the reader of the source-text new ways of understandingby analogy-difficult philosophical concepts.

Thus, it was only rational to consider that neither Titu Maiorescu's contemporary readers nor the readers of our times can exactly understand what the German philosopher meant when he used this specialized neologism. In this case, disambiguation can only originate in the context in which the word is being used, i. e. the one that implies a kind of alienation from certain philosophical concepts, as mentioned in the discussion about the previous sentence (6). Therefore, we consider that what the author meant herein both literal and metaphorical sense-is an adjustment (Rom. ajustare) of the eye when looking at a specific object, an adjustment made in accordance with the distance between the eye and the object of study.

The explanatory passage that follows the noun Ackommodation also raised great translation difficulties.

The source-text includes two subordinate clauses, as follows:

\section{[...], sofern sie nämlich auf dem gewöbnlichen, empirischen Standpunkte bleibt und dessen Irrthum festhält.}

The equivalent of this passage in $\mathrm{A}_{72 / 76}$ is as follows:

[...], intru căt remăne in marginile ințelegerii empirice obicinuite și-i continuă rátăcirea.

In later editions, $\mathrm{A}_{90}$ and $\mathrm{A}_{12}$, which are identical except for their orthography, the Romanian translation is as follows:

[...], întrucît pornesc din punctul de vedere al experienței obişnuite și urmează drumul ei rătăcit.

As we have already mentioned, this is an explanatory passage, which justifies the presence of the adverbial connector nämlich, whose semantics signals an explanation of the previous assertion and whose occurrence-when linking two clauses-is in a medial position in the second clause (Engel et al., 1993, p. 938).

The subordinate conjunction sofern, placed at the beginning of the first clause, indicates a limitation of the circumstances in which the verbal action in the main clause can occur. Its equivalent in Romanian can be a conditional conjunction or a phrase that indicates conditionality: dacă, în caz că or în măsura în care. This is the reason why we regard Titu Maiorescu's translation as inaccurate, since the causal conjunction intrucit, which was used in all editions as an equivalent for the German word sofern, distorted the message from the source-text.

The anaphoric pronoun sie, functioning as subject of the conditional clause, introduces a further semantic ambiguity in the source-text. A rapid evaluation of the previous context indicates the feminine noun in singular Ackommodation as its referent or, in other words, as a regent for the subordinate clause in which sie is the grammatical subject. Comparing all Romanian editions of translation discussed here, one can realise that Titu Maiorescu decided that the pronoun sie has another referent, which was-in factthe second feminine noun in singular in the previous context Auseinandersetzung. This incorrect attribution of reference for the anaphoric pronoun sie is not obvious in the first edition of translation $\mathrm{A}_{72 / 76}$, because the verb remăne, which is a literal equivalent for the German bleibt, is marked for singular and is thus in agreement with both nouns mentioned before and with their Romanian equivalents in the targettext who are also feminine singulars (expunerea and acomodare, respectively). In later editions, though, Titu Maiorescu chose another equivalent, a contextual one, and modalised the translation by changing the grammatical category of number for the verb he used. Thus, the Romanian verb pornesc (marked for plural) 
clearly indicates that the reference for the anaphoric pronoun sie is explicările (a plural noun), i.e. the Romanian equivalent of Auseinandersetzung. One may say that, in this case, a true translation would be the one which preserve in the target-text the ambiguity from the source-text. That would have happened if the equivalents in the target-text for the two nouns involved in the anaphoric relationship (Ackommodation and Auseinandersetzung) would have carried the same grammatical information (in gender and number) as their referents in the source-text. Nevertheless, the translating strategy chosen by Titu Maiorescu helped his readers to better understand a text operating with various philosophical concepts, an occupation they were not very much accustomed to.

The nominal group with the centre Standpunkte was another reason for Titu Maiorescu to revise his translation. In $\mathrm{A}_{72 / 76}$, the translation is textual, combining free transposition with word-by-word equivalents. Thus, the modifiers gewöhnlichen and empirischen have been literally transposed into the target-text as obicinuite and empirice, while the equivalent of the nominal phrase centre became a nominal phrase itself, marginile ințelegerii. Yet, its constituents (centre + modifier) are nowhere to be found in the semantic meaning of the source-text. In the previous sentence (6) the same noun Standpunkte had been translated using the semi-calque punct de vedere. In this case, the translation is more than a free one. In fact, it may be regarded as both an over-translation, since additional meanings are included in the target-text and an under-translation, since the message in the source-text was eluded.

In the subsequent editions, Titu Maiorescu changed his text offering a translation which also combined various strategies: he preserved the equivalent for Standpunkte in the semi-calqued form punctul de vedere, but he made changes as far as modifiers are concerned. These were regrouped into a noun phrase functioning as possessor for the centre: al experienței obişnuite.

The following coordinating conjunction $(u n d)$ indicates that the next clause (und dessen Irrthum festhält $)$ is coordinated with the previous one and has the same subordinating relation to their shared regent. Although the grammatical subject is here omitted, it can be easily inferred from the context. In addition, the noun phrase dessen Irrthum includes the relative pronoun (dessen) functioning as a determiner in genitive. The possessor for the centre of the noun phrase centre is- undoubtedly-the noun Standpunkte, since it is the only masculine noun in singular in the previous context and thus in perfect accordance with the form dessen of the relative pronoun.

The Romanian equivalent for the clause we discussed here is as follows:

\section{$\mathrm{A}_{72 / 76}$ : și-i continuă rătăcirea \\ $\mathrm{A}_{90}$ și $\mathrm{A}_{12}$ : și urmează drumul ei cel rătăcit.}

Comparing the two versions above, it is obvious that the most translation difficulties originated in both the polysemy of the German verb festhalten and in its combination with the noun Irrthum, functioning as a direct object for it. The German verb festhalten can literally mean 'to hold', 'to keep', 'to not let go', but metaphorically can imply 'to establish' or 'to ascertain'. Titu Maiorescu understood the noun Irrthum metaphorically, based on the sememe Irre, and chose the Romanian equivalent rătăcire, initially preserving its morphological value (in $\left.A_{72 / 76}\right)$, but changing it in later editions $\left(A_{90}\right.$ and $\left.A_{12}\right)$ by over-translating it into a noun phrase (drumul [...] cel rătăcit). In conclusion, although it may seem that the translator chose a different translation option in the later editions, he only chose another strategy of transposing the message into Romanian while preserving its meaning. In our opinion, the author of the original text did not intend to add a metaphorical meaning to the word Irrthum, but referred to the 'error' implied by an approach like the one described in his text.

Considering all the above, we advance here a new translation solution, as follows:

Prin urmare, întreaga abordare ce urmează a fi realizată aici se bazează-intr-o anumită măsurăpe o ajustare, în măsura în care aceasta presupune, aşadar, păstrarea unui viziuni empirice comune, asumându-și [totodată] eroarea-i. 
The two following sentences, (8) and (9), provide a logical conclusion of all the reasoning previously presented. This is indicated by the presence of the adverb demnach (Rom. conform celor spuse inainte, aşadar, in concuzie, astfel [considering all of the above, therefore, in conclusion, thus]).

\section{Demnach kann auch ibr Werth nur ein bedingter seyn, da selbst das Wort Eudämonologie} ein Euphemismus ist.

$A_{72 / 76}$ Astfel și valoarea unei asemene scrieri nu poate fi decăt relativă, fiindcă insuşi cuvěntul Eudaemonologie este un eufemism.

$A_{90} \quad$ Astfel și valoarea unei asemenea scrieri nu poate fi decât relativă, fiindcă insuș cuvěntul eudemonologie este un eufemism.

$\mathrm{A}_{12}$ Astfel și valoarea unei asemenea scrieri nu poate fi decît relativă, fiindcă însuși cuvântul eudemonologie este un eufemism.

The translation of sentence (8) into Romanian was made almost literally, with all necessary transpositions according to the different word order required by the two languages involved in translation. We should note the excellent solution found by Titu Maiorescu as far as the participial adjective bedingt is concerned. By using the adjective relativă, which does not appear as a direct equivalent of the German word (cf. DGR, s.v. bedingt), the translator succeeded in preserving both the entire meaning of the lexeme from the sourcetext and its morphologic and syntactic values.

The conclusion proceeded in sentence (9), which started with the connector ferner (Rom. mai departe [furthermore, moreover]).

(9) Ferner macht auch dieselbe keinen Anspruch aufVollständigkeit; theils weil das Thema unerschöpflich ist; theils weil ich sonst das von Andern bereits Gesagte hätte wiederholen müssen.

$\mathrm{A}_{72 / 76}$ Și nici in altá privință nu fac pretenția unei expuneri complecte, parte fiindcă tema nu se poate sfirşì niciodată, parte fiindcă atunci aș fi trebuit să repet ceea ce au zis și alții.

$\mathrm{A}_{90} \quad$ Dar și cu această reservă nu am pretenția unei expuneri complete, parte fiindcă tema nu se poate sfirșì niciodată, parte fiindcă atunci aș fi trebuit să repet ceea ce au zis și alții.

$\mathrm{A}_{12} \quad$ Dar și cu această rezervă nu am pretenția unei expuneri complete, parte fiindcă tema nu se poate sfirșì niciodată, parte fiindcă atunci ar fi trebuit să repet ceea ce au zis și alții.

The syntactic structure of this sentence includes a main clause and two subordinate clauses. Those two subordinates are causal clauses and in a relation of co-ordination with one another via a correlative disjunctive conjunction teils... teils... Causality is indicated by the presence of the subordinating conjunction weil, which is typical for this kind of subordinating syntactic relation, and which occurs here in combination with each of the two correlatives of the above-mentioned disjunctive.

All editions of the Romanian version of this sentence preserved its syntactic structure. There are, though, differences between editions, but they are set, on one hand, at lexical and semantic levels, and on another hand, at the discursive level. For instance, the grammatical subject of the main clause in the source-text is the anaphoric pronoun dieselbe. Its semantic referent should be searched in the previous context, and this operation took us back to sentence (7), where we found the noun Auseinandersetzung. The discourse in the Romanian version was personalised and thus modified into a first-person narration by changing the grammatical subject of the main clause. Titu Maiorescu's translation solution may not at all be unreasoned as it may seem, since the action implied by the abstract noun Auseinandersetzung is the writer of the text himself.

The equivalent of the adverb ferner was an adverbial phrase functioning as a pragmatic connector, yet there are different solutions in various editions: in altá privință in $\mathrm{A}_{72 / 76}$, and cu această rezervă in $\mathrm{A}_{90}$ and 
$\mathrm{A}_{12}$.

The German idiom keinen Anspruch machen has initially been translated by using a calque: nu fac pretenția. After revising his text for the 1980 publication, Titu Maiorescu adapted the idiom to the rules of Romanian language and used the correct phrase: nu am pretenția.

Arthur Schopenhauer continued his Introduction by presenting other works that had the same topic as his. The following sentence (10) offered an example in this regard, by naming one of the great representatives of Renaissance spirit, Gerolano Cardano, whom Arthur Schopenhauer mentioned by his Latin name. The subsequent sentence (11) includes the name of Aristotle, whose particular writing on eudemonology got, however, boldly criticised by Arthur Schopenhauer.

(10) Als in ähnlicher Absicht, wie gegenwärtige Aphorismen, abgefaßt, ist mir nur das sehr lesenswerthe Buch des Cardanus de utilitade ex adversis capienda erinnerlich, durch welches man also das hier Gegebene vervollständigen kann.

A $72 / 76$ Dintre alte cărți, care să fie scrise in aceeași intenție cu aforismele de față, imi aduc aminte numai de scrierea lui Cardanus de utilitate ex adversis capienda, care merită foarte mult a fi cetită și prin care se pot dar complecta cele zise aici.

$A_{90} \quad$ Dintre alte cărți, care să fi fost scrise in aceeaș intenție ca aforismele de faţă, imi aduc aminte numai de scrierea lui Cardanus de utilitate ex adversis capienda, care merită foarte mult să fie cetită și prin care se pot completà cele zise aici.

$\mathrm{A}_{12}$ Dintre alte cărți, care să fi fost scrise in aceeaș intenție ca aforismele de față, imi aduc aminte numai de scrierea lui Cardanus De utilitate ex adversis capienda, care merită foarte mult să fie citită și prin care se pot completa cele zise aici.

A morphologic and semantic analysis of the first sequence of this sentence (Als in ähnlicher Absicht, wie gegenwärtige Aphorismen, abgefaßt, ...) solves the problem raised by the polysemic conjunction als, revealing its modal value. The sequence in question does not contain a finite verb in the past tense, so that the temporal value of the conjunction may easily be discarded. Moreover, from the list of meanings included in any dictionary for the connector als, the most appropriate one that can be easily selected is the one that indicates that this conjunction was used to introduce additional information regarding a certain referent. This referent can be identified, on one hand, as the centre Buch of the noun phrase functioning as grammatical subject within the main clause, or, on the other hand, as the adjective erinnerlich functioning as predicative inside the finite verb of the same clause. This double semantic subordination generates the conclusion that the above-mentioned sequence is an attributive structure, which semantically belongs to the noun phrase functioning as grammatical subject of the main clause. The very complex structure of this nominal phrase is illustrated in the table below:

\section{Constituents of the noun phrase function- Function and features ing as grammatical subject of the main clause-sentence (10)} Als in ähnlicher Absicht, wie gegenwärtige attributive structure (built with the conjunction Aphorismen, abgefaßt, als + verbal phrase); prepositive; isolated by commas from the rest of the sentence; introduces ad-

das

sehr lesenswerthe

Buch ditional information (Engel et al., 1993, p. 762). determiner (definite article) determiner for modifier (intensifying adverb) + modifier (verbal adjective) centre of noun phrase (common noun) 
des Cardanus

de utilitade ex adversis capienda possessor (proper noun, in genitive, proclitically marked with the corresponding article) apposition; separated not by commas, but by graphic appearance

The table above reflects the fact that, beside the nominal nucleus (the noun Buch) accompanied by its usual constituents (determiner, modifier, possessor, apposition), the noun phrase functioning as a grammatical subject within the main clause includes a further and more complex attributive structure adding new information about the lexeme-centre Buch. The attributive structure incorporates a verbal phrase whose centre is the non-finite abgefaßt. As an equivalent for this participle, the Romanian version selected one of its most general synonyms ('to write') and translated it as a conjunctive in the present tense (să fie scrise in $\mathrm{A}_{72 / 76}$ ) or in the past tense in subsequent editions (să fifost scrise, in $\mathrm{A}_{90}$ and $\mathrm{A}_{12}$ ).

In order to help his readers understand the meaning within this passage, the translator was bound to change the attributive structure from a dominantly verbal one (since it included a verbal phrase) into a noun phrase introduced by the partitive preposition dintre:

\section{Dintre alte cărți, care să fie/să fi fost scrise in aceeaș intenție ca aforismele de față.}

The noun cărți is the centre of the nominal group introduced by the partitive dintre and is the semantic equivalent of the German noun Buch, which occurs only later in the source-text, when it is translated as scriere. So, by introducing an additional attribute to indicate the selection of an object from a group of similar ones, Titu Maiorescu was bound to change the verbal phrase from the source-text into a nominal one, whose centre (inexistent in the source-text) had to semantically correspond to the noun functioning as a subject within the main clause; in other words, he needed a synonym for it.

The predicate of the main clause, ist [mir] ... erinnerlich, is built with the copula ist $\rightarrow$ sein and the predicative erinnerlich (Rom.: $\approx$ care se află în memorie, care poate fi apelabil din memorie, care îmi vine în minte, de care imi amintesc). The inexistence in Romanian of an equivalent for this predicative compelled the translator to use a verb phrase with the same meaning as the above mentioned predicate (Rom. [imi] aduc aminte), which required another grammatical subject than the one present in the source-text. This subject, even though remained unexpressed in the Romanian version, is totally recovered from the form of the reflexive pronoun $\hat{\imath} m i$. In our opinion, in this case, Titu Maiorescu found the best translating solution.

The same happened in the case of the adjective lesenswert, a derivative by suffixation with -wert (Rom. demn de a fl ...) from the verb lesen (Rom. a citi). A literal translation for this adjective would have burdened the syntax of the Romanian sentence, therefore Titu Maiorescu chose to extract it from the noun phrase in which it was included in the source-text and translate it separately as a relative clause functioning as attribute: care merită ... a fi cetită in $\mathrm{A}_{72 / 76}$, and care merită ... să fie cetită in $\mathrm{A}_{90}$ and $\mathrm{A}_{12}$.

The syntactic structure of the sentence in the source-text includes a main clause and a relative clause introduced by the sequence [durch (preposition) + welches (relative pronoun)]. The latter preserved its value of relative clause in the target-text. Therefore, and because the equivalent of the adjective lesenswert is also a relative clause, the translator chose to co-ordinate them with the conjunction şi, although that was not present in the source-text.

The adverb also, placed in middle position in a relative clause, may seem as functioning as a consecutive connector, but it may also be a particle characteristic for spoken German (Abtönungspartikel), thus with no clear-cut meaning, signalling here a relativisation of the message. In $\mathrm{A}_{72 / 76}$, the translator chose for it the equivalent dar, which is in fact an older form for aşadar; in other words, he considered it as being a consecutive adverb. In subsequent editions, T. Maiorescu totally avoided its translation, probably because it seemed redundant to him. Indeed, if we read the two versions, we could easily admit that this word does not really carry any meaning and its omission within the target-text does not alter the meaning from the source-text.

Greater difficulties of translation occur when a German concept does not have a direct equivalent in Romanian, especially when philosophical texts are involved. This is the case of the verbal noun das (bier) 
Gegebene. The Romanian equivalent given by Titu Maiorescu in his version of translation (cele zise (aici)) included an attribute derived from the verb a zice, however not the one in the source-text, geben (Rom. a da).

Analysing the difficulties raised by translating this sentence into Romanian and the ways the translator succeeded in overcoming them, we consider the Romanian equivalent of this sentence a real achievement for Titu Maiorescu as a translator, since he created a text which is both coherent for his readers and true to the meaning in the source-text.

Arthur Schopenhauer continued his text by mentioning Aristotle as being one of his few predecessors who philosophically discussed the issue of happiness, an approach that got however criticized by the German philosopher.

(11) Zwar hat auch Aristoteles dem 5. Kapitel seines 1. Buchs seiner Rhetorik eine kurze Eudämonologie eingeflochten: sie ist jedoch sehr nüchtern ausgefallen.

A 72/76 E drept, că și Aristoteles a intercalat in Retorica sa cap. 5 al cărții 1 o Eudaemonologie scurtă; aceasta ănsě nu i-a prea isbutit, ci se arată mărginită intr’o abstracție fără viaţă.

$\mathrm{A}_{90} \quad$ Ce e drept, și Aristotel a intercalat in Retorica sa (cap. 5 al cărții 1) o Eudemonologie scurtă; cu aceasta insě nu a prea isbutit, și lucrarea a remas mărginită intr’o abstracție fără viață.

$\mathrm{A}_{12} \quad$ Ce e drept, și Aristotel a intercalat in Retorica sa (cap. 5 al cărții 1) o eudemonologie scurtă, care însă nu a prea izbutit, ci a rămas mărginită într-o abstracție fără viață.

The sentence (11) began with the adverb zwar, whose equivalent in $A_{72 / 76}$ is a verbal structure with an adverb as predicative ( $e$ drept) and which selects a subsequent conjunction ( $c \breve{a})$ to introduce the subjective clause. This translating solution preserved the meaning from the source-text, although separating the verbal structure from the rest of the sentence by comma is an improper punctuation option, which might be due to the instability of the Romanian language at the time the translation was made (including here its punctuation system). In later editions of his translation, Titu Maiorescu chose the phrase ce e drept, which is - correctly, this time-isolated by comma from the rest of the sentence, being regarded as a pragmatic connector used to express a concessive confirmation of the subsequent proposition.

The next clause, sie ist jedoch sehr nüchtern ausgefallen, is the verdict Arthur Schopenhauer ironically applied to Aristotle's approach on eudemonology and is a relatively simple clause as far as its syntactic structure is concerned. Yet, it raised difficulties for the translator, since it produced different equivalents in each of the Romanian editions we discuss here, as follows:

$$
\begin{aligned}
& \mathrm{A}_{72 / 76} \text { : aceasta ănsè nu } i \text {-a prea isbutit, ci se arată mărginită intr’o abstracție fără viață. } \\
& \mathrm{A}_{90}: \text { cu aceasta insě nu a prea isbutit, şi lucrarea a remas mărginită intro abstracție fără viață. } \\
& \mathrm{A}_{12}: \text { care insă nu a prea izbutit, ci a rămas mărginită într-o abstracție fără viață. }
\end{aligned}
$$

It is noticeable from the very beginning that this relatively simple clause was transferred into Romanian in the form of a sentence with two main clauses coordinated initially by an adversative conjunction ( $c i$ in $\mathrm{A}_{72 / 76}$ and $\left.\mathrm{A}_{12}\right)$ and in a later editions by a copulative one $\left(s i\right.$ in $\left.\mathrm{A}_{90}\right)$. The adversative $c i$ seem rather inappropriate in our opinion, since its meaning implies a context in which an assertion gets corrected and replaced with another. Yet, in this case, the assertions in both clauses concurred thematically to the same conclusion, i.e. that the respective approach was not a very successful one. When revising his translation for its publishing in 1890, Titu Maiorescu seemed to have realized the inappropriate use of the adversative and changed it with și. Still, in the $\mathrm{A}_{12}$ edition (considered to be the definitive one) the adversative $c i$ reappeared for reasons we do not understand and which may be due to the polysemy of this conjunction.

The predicate ist ... ausgefallen was translated as a negative (nu a izbutit) modified by the adverb prea. The translator was probably discontent with this initial solution (aceasta ănsě nu i-a prea isbutit), since he 
added new information in form of an additional clause: ci se arată mărginită intr’o abstracție fără viață. In the following edition $\left(A_{90}\right)$, syntactical changes have been applied to both clauses. The grammatical subject of the first one was modified by introducing the author of the respective approach (cu aceasta insě nu a prea isbutit); at the same time, the subject of the second clause did not remain unexpressed, but was clearly mentioned as lucrarea (și lucrarea a remas mărginită intr’o abstracție fără viață). In the final version $\left(\mathrm{A}_{12}\right)$, the first clause was changed into a relative clause (care însă nu a prea izbutit), while the second one was introduced by the adversative $c i$ (ci a rămas mărginită într-o abstracție fără viață). The result here was a combination of the previous translating solutions.

Disregarding the variety of lexical and syntactic solutions in the three editions of the Romanian version analysed here, the translator used over-translation in all three cases in his attempt to recover all the meanings included in this passage of the source-text. The German verb ausfallen, for instance, when used neutrally means 'a avea un rezultat' (Eng. to result in), but when used in a derogatory way implies 'a da greș' (Eng. to fail) (cf. DUDEN, s.v. ausfallen). The presence of the concessive adverb jedoch inside the clause would lead the reader of the source-text to select the second meaning of the German verb, which T. Maiorescu also transferred in his translation.

The adjective nüchtern contributed to a derogatory meaning of the context. Its Romanian equivalents in contemporary bilingual dictionaries are words like 'lucid', 'sobru', 'treaz' or, in certain contexts, 'pe stomacul gol'. Yet, when Arthur Schopenhauer wrote his works, this adjective would have had a further meaning, i. e. 'fără sare,' 'fad', which became at present obsolete. Taking into account the occurrence in the clause of a concessive adverb (jedoch), the adjective nüchtern acquires pejorative connotations at its turn. Therefore, it is right to believe that A. Schopenhauer used this lexeme in its metaphorical meaning in that specific context, as it was used in the spoken German of his time.

After the short divagation of mentioning his predecessors who had tackled the same topic of eudemonology, Arthur Schopenhauer strictly differentiated himself from them by emphasizing the originality an approach like that should exhibit.

(12) Benutzt habe ich diese Vorgänger nicht; da Kompiliren nicht meine Sache ist; um so weniger, als durch dasselbe die Einheit der Ansicht verloren geht, welche die Seele der Werke dieser Art ist.

$\mathrm{A}_{72 / 76}$ De intrebuințat n'am intrebuințat pe acești predecesori, căci a compila nu e obiceiul meu, cu atăt mai puțin, cu căt atunci se perde unitatea, care este sufletul operilor de acest soiu.

$\mathrm{A}_{90} \quad$ De intrebuințat n’am intrebuințat pe acești premergětori, căci a luà de la alții nu e obiceiul meu, cu atât mai puțin, cu cât atunci se pierde unitatea, care este sufletul scrierilor de acest fel.

$\mathrm{A}_{12}$ De întrebuințat n-am întrebuințat pe acești premergători, căci a lua de la alții nu e obiceiul meu, cu atît mai puțin, cu cît atunci se pierde unitatea, care este sufletul scrierilor de acest fel.

A. Schopenhauer's self-delimitation from his predecessors was stylistic marked by thematising the participle benutzt, in other words by changing the natural word order in German language. The Romanian equivalent of such a structure uses a supine and an adverbial of relation which belongs to a semantic group called iterative correlatives: de intrebuințat, n-am intrebuințtat (cf. GBLR, p. 557). The adverbial included the negation, which according to German word order, was placed in a final position in the source-text.

The Romanian equivalent for the German noun Vorgänger was predecesori in $\mathrm{A}_{72 / 76}$, while in subsequent editions the calqued premergători occurred. The same happened with the neologism a compila in $\mathrm{A}_{72 / 76}$, which disappeared in later editions and got changed into a verbal phrase, a lua de la alții. So, by wanting to avoid neologisms where he thought Romanian equivalents were available, Titu Maiorescu often resorted to calques, which at least in these cases seem rather inappropriate for those specific contexts. 
Surely the use of neologisms would be absolutely natural for Romanian contemporary readers of the translation,

The last two sentences of the Introduction seem to strengthen A. Schopenhauer's fame as 'pessimist philosopher'. The metaphor of dichotomous division of the world between sages and fools was used by the author to express his conviction that his advice would not change humankind in any way, exactly as wise men's words are not credited by fools. He thus resigned himself to the usefulness of his enterprise.

(13) Im Allgemeinen freilich haben die Weisen aller Zeiten immer das Selbe gesagt, und die Thoren, $d . h$. die unermeßliche Majorität aller Zeiten, haben immer das Selbe, nämlich das Gegentheil, gethan: und so wird es denn auch ferner bleiben.

A $72 / 76$ De altmintrelea nu trebue să uităm, că ințelepții tuturor timpurilor ne-au dat totdeauua aceeași invěțătură, ear nebunii adică imensa majoritate a tuturor timpurilor, au urmat totdeauna aceeași practică, adică cea contrară: și așa vor remănè lucrurile și deacum inainte.

$\mathrm{A}_{90} \quad$ De altminteri nu trebue să uităm, că ințelepții tuturor timpurilor ne au dat totdeauua aceleași povețe, ear nebunii-marea majoritate a tuturor timpurilor-au respuns totdeauna cu aceleași fapte, adecă cu fapte contrarie; și așa vor rěmănè lucrurile și de acum inainte.

$\mathrm{A}_{12} \quad$ De altminteri nu trebuie să uităm, că ințelepții tuturor timpurilor au dat totdeauna aceleași povețe, iar nebunii-marea majoritate a tuturor timpurilor-au răspuns totdeauna cu aceleași fapte, adică cu fapte contrarii; și așa vor rămânea lucrurile și de acum inainte.

The adverb freilich (Rom. totuşi, cu toate acestea), preceded by the generalizing adverbial phrase im Allgemeinen (Rom. in general, in mod normal/obişnuit, in principal, etc.) marked the return to a pessimistic reality - which is characteristic for Arthur Schopenhauer's philosophy. Over-translation was again used by Titu Maiorescu in this case, by introducing a finite clause (de altminteri nu trebuie să uităm) that has no correspondent in the source-text and which requires a direct object in form of a subordinate clause introduced by the conjunction $c \breve{a}$. The contrastive analysis performed on both semantic and pragmatic level for the two passages (original and translation) generated two main observations. First, the generalising intention of the original (see im Allgemeinen) is rendered in the Romanian translation in the form of the implicit pronoun noi, with the implied meaning of 'we all'. Second, the concessive meaning within the original text is rendered in the Romanian translation both as an adverbial phrase (de altminteri) functioning as a pragmatic connector of concession and as an additional message (nu trebuie să uităm), which semantically signals that what was there reminded was a fact that implies a resignation in front of a certainty, or a concession to reality.

Over-translation is, in our opinion, a translating method that-unlike paraphrasing-could induce in the target-text additional meanings which are absent from the source-text, or even deviations from its intentionality. Yet, in the case discussed here, this method did nothing else but facilitating the message transfer from the source to the target. Moreover, the stylistic features of the target-text were thus improved by avoiding two adverbs from clinging together (în general and totuşi).

Sentence (13) includes two symmetric predicates corresponding to the actions of the two groups building the world, according to A. Schopenhauer: the sages and the fools. The sages haben ... das Selbe gesagt (Rom. au spus ... același lucru), while the fools haben ... das Selbe gethan (Rom. au facut ... același lucru). Titu Maiorescu translated freely both predicates using verbal phrases. Thus, the equivalent of sagen (Rom. a spune) is a da învățătură in $\mathrm{A}_{72 / 76}$ or a da povețe in later editions, while the equivalent of tun (Rom. a face) is a urma o practică or a răspunde cu fapte, respectively. In spite of their lexical hesitations, these free translations demonstrate once again Titu Maiorescu's creativity.

From the lexical point of view, further changes are also obvious: the neologism imens $a$ used in $A_{72 / 76}$ 
is absent from the later editions of the Romanian translation, in fact, it was replaced with the adjective marea; ; the impersonal es was translated as a concrete noun in plural lucrurile; the German noun Gegentheil (Rom. opus, contrar) was rendered as a noun phrase which uses a part of the verbal phrase (i.e., the noun) and recovers the meaning of the original lexeme by means of an adjective. Thus, in $\mathrm{A}_{72 / 76}$, the Romanian equivalent of Gegentheil is cea contrară, where the demonstrative pronoun cea finds its referent in the previous noun practica, which occurred in the morphologic structure of the phrasal verb. In later editions $\left(\mathrm{A}_{90}\right.$ and $\left.\mathrm{A}_{12}\right)$ the equivalent followed the same scheme but in another form: fapte contrarii.

The last sentence of the Introduction incorporates a quotation of French Enlightenment philosopher Voltaire, which in fact supports Arthur Schopenhauer's pessimistic vision on the world:

Darum sagt Voltaire: nous laisserons ce monde-ci aussi sot et aussi méchant que nous l'avons trouvé en y arrivant. ${ }^{2}$ [Wir verlassen diese Welt so töricht und so böse, wie wir sie bei der Ankunft vorgefunden haben.]

$\mathrm{A}_{72 / 76}$ Deaceea zice Voltaire: Nouslaisserons ce monde-ci aussi sot et aussi méchant que nousl'avons trouvé en y arrivant.

$\mathrm{A}_{90} \quad$ De aceea zice Voltaire: Nous laisserons ce monde-ci aussi sot et aussi méchant que nous l'avons trouvé en y arrivant.

$\mathrm{A}_{12} \quad$ De aceea zice Voltaire: Nous laisserons ce monde-ci aussi sot et aussi méchant que nous l'avons trouvé en y arrivant.

Predictably, the translation of this sentence did not raise any difficulty, since the sentence includes two German words only, the others being a proper noun (Voltaire) and a quotation in French, which both the author of the original and the translator preserved it as such. In doing so, both writers considered that a translation from French would be pointless to their respective readers. Their reasons of not translating a French quotation are somewhat similar and reflect their relation as writers with their target-audience. On one hand, Arthur Schopenhauer always claimed that his audience is an educated one even when the topic of his writing was more general, as was the case of the Aphorisms. On the other hand, Titu Maiorescu's readers were highly familiar with the use of the French language, since it was the most common foreign language known at that time. Considering the fact that this is no longer valid today, it is most probable that a translation of the French quotation, even as a footnote, would be welcomed by Romanian contemporary readers.

\section{Results of the research}

3.1. Comparing the various editions of the Romanian translation from Arthur Schopenhauer's Aphorisms, one can easily see the many differences between the versions as far as their orthography is concerned. The present article did not pursue them, since they were due to the system instability of the time when the translation was made. It is known that a complete unification of the orthographic rules was realized no sooner than the end of the $19^{\text {th }}$ century;

3.2. The version that displays the most text modifications compared to the previous version is $A_{90}$, which is the one occasioned by the Aphorisms being published in a volume. The previous version $\left(A_{72 / 76}\right)$ is, in fact, the first of a series of five editions of translation that Titu Maiorescu published during his life. It preceded the $\mathrm{A}_{90}$ version with almost two decades and was published in the Romanian literary journal Convorbiri literare between 1872 and 1876. Later editions also display changes in the text, but they are minor and few in number. One can fairly assume that, at least as far as this first chapter is concerned, $A_{90}$ is almost identical with the edition considered to be the definitive one $\left(A_{12}\right)$;

3.3. Compared to $A_{72 / 76}$, the $A_{90}$ edition is a translation that is less true to the source-text, but more intelligible to Romanian readers of the time. After having published his first edition, Titu Maiorescu 
decided to revise his text with the overt intention to refine it both grammatically and stylistically, as far as Romanian language was concerned (see the Preface of the edition published in a volume, in 1890). Thus, a series of phrases that have been previously translated quasi-literally in $\mathrm{A}_{72 / 76}$ underwent stylistic refinement in $\mathrm{A}_{90}$. For instance, in sentence (3), the German phrase von endloser Dauer was initially translated (in $\mathrm{A}_{72 / 76}$ ) as de o durată nesfirșită. In $\mathrm{A}_{90}$, after having revised his text, Titu Maiorescu gave another equivalent for it: nesfirșit de lungă. Here, the adjectival adverb is accompanied by an adverbial modifier to express the superlative and preserves thus the meaning from the source-text, being at the same time a more appropriate actualization of the circumstantial adverbial for the predicate să o vedem.

3.4. As far as translating strategies are concerned, Titu Maiorescu mostly used literal translation in his first edition $\left(\mathrm{A}_{72 / 76}\right)$ of the Aphorisms (Introduction), though he made all the necessary transpositions resulted from the differences in terms of word order between the two languages involved. Nevertheless, the translator did not hesitate to sometimes use modalisation, often accompanied by over-translation and sometimes by under-translation. There are enough cases in which all these three strategies are being used in the same sentence. For instance, in sentence (1), the translator avoided the personal pronoun $e u$ at the beginning of the paragraph, as it was in the source-text. He resorted to a transposition by thematising a direct object, converting it to a grammatical subject in the target-text. If the translator had used literal translation only, without modalising it by changing the word order, the target-text would have acquired additional pragmatic meanings - in this case, an emphasis on the role of the actant. Still in sentence (1), T. Maiorescu used the under-translation strategy by not giving a Romanian equivalent for the German noun Begriff. The aim of his action was to facilitate the reading of a complex text (sentence) operating with philosophical concepts and their definitions. The same sentence (1) also displays an over-translation though paraphrasing. That happened when the German adjective immanent was not directly translated as imanent, using a Romanian neologism, but was converted into a paraphrase: obişnuit [...] färă vreo metafisică transcendentă. By adopting this strategy, the target-text had to be syntactically reorganized (the original sentence was fragmented in order to avoid a heavy syntax). Nevertheless, T. Maiorescu preferred it over a neologism which most of his readers would not have really understood. The strategy of overtranslation was also employed in cases in which Arthur Schopenhauer used anaphoric pronouns, mostly demonstrative pronouns: diese, eine solche, ein solches (see sentences (2), (6), etc.). The translator preferred to introduce into the target-text the respective correlative noun, thus avoiding the Romanian equivalent of the pronoun as such. The goal was obvious, i.e. to prevent vagueness in the process of reception.

3.5. From the lexical point of view, T. Maiorescu fought against the assault of neologisms into Romanian language, a trend advocated by Transylvanian linguists of the time. This fight manifested itself especially when Titu Maiorescu made the first revision of his translation from the Aphorisms in order to publish it in a volume, in 1890. In the first edition $\left(\mathrm{A}_{72 / 76}\right)$, Titu Maiorescu consistently employed literal translation and used a series of neologisms of Latin origin. The subsequent editions, beginning with the first revision in 1890, displayed local lexemes, many of them of Turkish or Slavic origin. For example, in sentences (1) and (4), the initial Romanian equivalent for the German Anweisung was invéțătură, a lexeme derived from a Latin base. In later editions, he changed it into călăuza probably with the intention of limiting the semantic range of the first one, which besides the meaning of 'sfat', 'povață', can also cover a more general meaning, such as 'instruire', 'instrucțiune', 'știință de carte', erudițiune' (cf. Şăineanu, 1908, p. 339). A further example in this regard is found in sentence (4) where the Romanian equivalent of the German verb entsprechen initially was a corespunde, a lexeme of Latin origin and a borrowing from French into Romanian. In later editions, this would be changed into a reflexive verb, 'a se potrivi', of Slavic origin, which the translator probably considered more familiar to his readers at the end of the $19^{\text {th }}$ century. It is thus obvious that the translator Titu Maiorescu tried to remain true to the German text and, at the same time, did not hesitate to use lexemes which are not necessarily of Latin origin, but represented equivalents that covered the meanings in the source-text and, at the same time, were more familiar to Romanian readers of that time. 
Yet, there were cases in which rather inappropriate calques were used when neologisms were avoided. For example, in sentence (12), the initial Romanian equivalent for Vorgänger was predecesori (a neologism); the subsequent editions changed it into premergători, which is an ill-suited loan translation of the German noun.

3.6. The greatest difficulties in translating this first chapter of the Aphorisms have been determined by the absence in Romanian language of direct equivalents for German specific lexical and syntactic structures such as nouns compound by juxtaposition, the Konjunktiv I verbal mode, or the gerundive structure functioning as an attribute. In most cases, Titu Maiorescu succeeded in solving the problems derived from the differences between the two languages involved in the translation process, displaying great creativity in handling "the compensatory virtues of Romanian language" (cf. I. Kohn, translation mine). Two examples are here offered: the first one is in sentence (7), where an attributive gerundive was translated as a participle functioning as modifier. Thus, the structure die [...] hier zu gebende [Auseinandersetzungen] was translated as [expunerea] făcută în... $\left(\mathrm{A}_{72 / 76}\right)$, or [explicările] cuprinse în ... ( $\mathrm{A}_{90}$ și $\left._{\mathrm{i}} \mathrm{A}_{12}\right)$. A literal translation of this structure (the attributive gerundive) would have been in accordance with the rules of translating a gerundive into Romanian ('ce urmează a fi dată/date aici'), but it would have also resulted in a rather poor-if not deficient-style in the target-text. The second example is in sentence (4), where the German verb entsprechen was used by Arthur Schopenhauer in a German specific verbal mode, Konjunktiv I, with no direct equivalent in Romanian. The translating solution Titu Maiorescu found was the insertion into the discourse of the adverb vreodată which, as a referent for an indefinite time, transfers into the target-text a fraction of the doubt expressed by the verbal mode Konjunktiv $I$ in the source-text.

3.7. Additional difficulties derived from the fact that Romanian language was not sufficiently developed at the end of the $19^{\text {th }}$ century as far as its philosophical terminology is concerned. Thus, in sentence (5), Arthur Schopenhauer used the adjective angeboren in an abstract metaphysical sense, but T. Maiorescu translated it as înnăscută in all of the three versions discussed here. At that time, the Romanian lexeme înnăscut meant 'adus odată cu nașterea'. Now, a usual synonym listed by any contemporary bilingual dictionary is 'congenital', which does not match the meaning in the source-text anymore. A more appropriate equivalent for the contemporary reader would be the adjective 'inerent' or even 'instinctiv'.

Impediments in translating philosophical terminology are more obvious in sentence (6), when Titu Maiorescu had to find the equivalent of the following noun phrase:

... [von dem] höheren, metaphysisch-ethischen Standpunkte, zu welchem meine eigentliche Philosophie hinleitet.

The main point of interest here are the two adjectives preceding the centre Standpunkte: böheren and metaphysisch-etischen. They have been each translated by using different strategies. Literal translation was used for the first one, which became mai inalt, although a contextual translation would have been more appropriate in our opinion, since it describes an abstract noun,. Some examples in this regard would be: 'superior', 'elevat', or 'rafinat'. For the second, compound adjective metaphysisch-ethisch(en), T. Maiorescu used a modalised translation by changing it into a noun phrase. Initially (in $\mathrm{A}_{72 / 76}$ ) he chose as head of the phrase the noun derived from the first adjective of the compound, metafizică, while the second adjective became an attribute, etică. Later editions recorded both a reversed attribution of roles and a replacement of the noun etică with a synonym. Thus, metafizica etică (Eng.: ethical methaphysics) from the first edition became morala metafizică (Eng.: metaphysical morality) in later ones.

Within the discussion regarding the development of Romanian philosophical (meta)language, it is worth mentioning that T. Maiorescu, when referring to A. Schopenhauer's philosophical system in a footnote to sentence (5), initially indicated it as filosofia [lui Schopenhauer], while in subsequent editions he changed it into doctrina. The permutation was determined by his wish of limiting the semantic range of 'filosofie' to only one meaning: sistemă particulară a unui filozof (cf. Șăineanu, 1908, p. 251) and discarding other more general meanings such as știință [...] care interpretează și reflectă realitatea or 
concepție generală despre lume și viață (cf. Șăineanu, 1908, p. 251). In the same footnote, the title of A. Schopenhauer's main work was initially translated as lumea ca voință și idée. The $\mathrm{A}_{90}$ version displayed it as lumea ca voință și ca representare, while the definitive version $\mathrm{A}_{12}$ recorded the title which remained valid till present: Lumea ca voință și reprezentare. Moreover, there were also differences regarding the registration of the explanatory addendum as a translator's footnote. That was recorded as $T$. in $A_{72 / 76}$ and as Trad. in $\mathrm{A}_{90}$. Only in $\mathrm{A}_{12}$, Titu Maiorescu came up with the notation which is now still in use (Nota trad.).

3.8. Comprehension of the source-text is sometimes distorted in certain passages of the target-text, whose revision seems more than necessary; consequently, new translating options are here provided for those passages, since we now benefit from a sufficiently developed philosophical terminology in Romanian language and, in addition, all of the neologisms Titu Maiorescu thought were less familiar to his readers have become widely and officially accepted nowadays. For example, sentence (6) was here provided with a new translating solution, as follows:

Fraza (6): Um eine solche dennoch ausarbeiten zu können, habe ich daher gänzlich abgehn müssen von dem höheren, metaphyf[s]isch-ethischen Standpunkte, zu welchem meine eigentliche Philosophie binleitet.

New translation solution: De aceea, pentru a putea construi, totuşi, o astfel de teorie, a trebuit să renunț în totalitate la viziunea elevată, metafizică și etică, la care se referă, de fapt, filosofia mea.

A particular case of the discussion regarding the meaning distortion within the target-text is represented by the very title of A. Schopenhauer's work discussed here. Titu Maiorescu's version of translation recorded two slightly different titles: Aforisme pentru înțelepciunea în viață (in $\mathrm{A}_{72 / 76}$ ) and Aforisme asupra ințelepciunii în viață (in $\mathrm{A}_{90}$ and all the subsequent editions). We have already advanced the suggestion that the initial version of the title is the more appropriate one, i.e. Aforisme pentru ințelepciunea in viață (Vârlan, 2016). Our opinion is endorsed by the fact that the preposition 'pentru' seems to better be in accordance with the original author's intention, which was to offer his readers advice on how to live wisely, thus obtaining happiness and comfort in life, in other words, advice 'for' a happy and satisfying life, according to German philosopher's views.

\section{Conclusions}

Within the Romanian cultural landscape at the end of the $19^{\text {th }}$ century, the importance of the emergence of a translated version of A. Schopenhauer's Aphorisms - just two decades after its publication in Berlinis undeniable.

The translator, Titu Maiorescu, exhibited great creativity in his enterprise of translating philosophical texts in general and Arthur Schopenhauer's works in particular. At the time the Romanian version of the Aphorisms was being made, the translator had to overcome a series of difficulties derived from the fact that Romanian philosophical language was not sufficiently developed as to stand next to a refined German philosophical terminology. Moreover, the language used by A. Schopenhauer was a very complex and difficult one even for Germanic scholars. As shown in the present article, Titu Maiorescu employed various translating methods and strategies that are worthy of being studied in order to observe and further use the compensation means of Romanian language when involved in the act of translating philosophical works (German philosophical works, in particular).

According to literature, it is well known that a translation is never perfect, only perfectible. Certain scholars of Translation Studies placed translation equivalence in direct dependence with the horizons of expectation of the target-audience. A translation is said to be good when it best meets the needs of the target-audience at the time it is accomplished. The specific analysis performed here on the Romanian version of Arthur Schopenhauer's Aphorisms proved the translator's manifested intention to permanently 
make his text adequate to both the target-language (Romanian) and the target-audience at the time the translation was written (Romanian readers in the late $19^{\text {th }}$ century). This permanent search for adequacy confers Titu Maiorescu's endeavour a major importance within Romanian culture, yet this does not necessarily mean it cannot be further adapted to the needs of Romanian contemporary readers.

\section{Bibliography}

DEX = Dicționarul explicativ al limbii române, Academia Română, Editura Univers Enciclopedic Gold, București, 2012.

DGR = Dicționar german-român, Institutul de lingvistică “Iorgu Iordan - Al. Rosetti” al Academiei Române, Editura Univers Enciclopedic Gold, București, 2010.

DUDEN = Deutsches Universalwörterbuch, 3., neu berbeitete und erweiterte Auflage, Dudenverlag, Mannheim, Leipzig, Wien, Zürich, 1996.

Engel, U., Isbășescu, M., Stănescu, S. \& Nicolae, O. (1993). Kontrastive Grammatik Deutsch-Rumänisch, Julius Groos Verlag, Heidelberg.

GBLR = Pană Dindelegan, G. (coord.) (2010). Gramatica de bază a limbii române, Editura Univers Enciclopedic Gold, București.

Hochfeld, S. (1912). Das Künstlerische in der Sprache Schopenhauers, Verlag von Johann Ambrosius Barth, Leipzig, [online].

Kohn, I. (1983). Virtuțile compensatorii ale limbii române în traducere, Editura Facla, Timișoara.

Rieger, M. (2006/2007). Ein Dativ-e, wie es im Buche steht... Empirische Untersuchung der phraseologisch gebundenen Verwendung des Dativ-e, [online].

Schopenhauer, A. (1872). Aforisme pentru ințelepciunea in viață, Traducere de T. Maiorescu, in "Convorbiri Literare", year VI, no. 8, Tipografia Societății Junimea, Iași.

Schopenhauer, A. (1876-1877). Aforisme pentru ințelepciunea in viață, traducere de T. Maiorescu, in "Convorbiri Literare”, year X, no. 1-12, Tipografia Societății Junimea, Iași.

Schopenhauer, A. (1890). Aforisme asupra înțelepciunii în viață, traducere de Titu Maiorescu, Editura Librăriei Socecu \& Comp., București.

Schopenhauer, A. (1912). Aforisme asupra înțelepciunii în viață, traducere de Titu Maiorescu, Editura Librăriei Socecu \& Comp., București.

Șăineanu, L. (1908). Dicţionar universal al limbei române, a opta edițiune, revăzut și adăogit la Ediția VI-a, Editura „Scrisul românesc" S. A., [online].

Vârlan, C.I. (2016). Translation difficulties in the Romanian version of Arthur Schopenhauer's Aphorisms. A contrastive and diachronic analysis (I), in "Diacronia”, 3, Feb. 12, art. A35, Crossref. 